\title{
PENGARUH INOVASI PRODUK TERHADAP NIAT PEMBELIAN ULANG DIMEDIASI OLEH KEPUASAN KONSUMEN
}

\author{
I. B Panca Putra $\mathbf{P}^{1}$ \\ Ni Made Wulandari Kusumadewi ${ }^{2}$ \\ ${ }^{1,2}$ Fakultas Ekonomi dan Bisnis Universitas Udayana, Bali, Indonesia \\ e-mail: happenglory.hg@gmail.com
}

\begin{abstract}
ABSTRAK
Tujuan penelitian ini adalah untuk mengetahui pengaruh inovasi produk terhadap niat pembelian ulang dimediasi oleh kepuasan konsumen (Studi pada Bakery Patisserie \& Café Sanur). Penelitian ini dilakukan di Kota Denpasar dengan teknik analisis data Path Analisis. Ukuran sampel yang didapat dengan menggunakan metode purposive sampling sebanyak 110 responden. Berdasarkan hasil analisis dapat dikemukakan bahwa inovasi produk berpengaruh positif dan signifikan terhadap kepuasan konsumen pada Bakery Patisserie \& Café Sanur. Inovasi produk berpengaruh positif dan signifikan terhadap niat beli ulang konsumen pada Bakery Patisserie \& Café Sanur. Kepuasan konsumen berpengaruh positif dan signifikan terhadap niat beli ulang konsumen pada Bakery Patisserie \& Café Sanur. Kepuasan konsumen memediasi pengaruh positif inovasi produk terhadap niat beli ulang konsumen pada Bakery Patisserie \& Café Sanur. Saran yang dapat direkomendasikan sebagai produsen, Bakery Patisserie \& Café Sanur harus menjaga rasa yang enak dan meningkatkan hasil produksi sehingga konsumen senang dan terus ingin berbelanja. Harus tetap mempertahankan rasa puas dari konsumen baik dari segi layanan, tampilan makanan, serta rasa dari makanan itu sendiri yang menjadi hal utama yang dicari oleh setiap konsumen.
\end{abstract}

Kata kunci: inovasi produk, kepuasan konsumen, niat beli ulang

\begin{abstract}
The purpose of this study was to determine the effect of product innovation on repurchase intention mediated by consumer satisfaction (Study at Patisserie Bakery \& Café Sanur). This research was conducted in city of Denpasar with data analysis techniques. The sample size obtained by using purposive sampling method was 110 respondents. Based on the results of the analysis it can be stated that product innovation has a positive and significant effect on customer satisfaction at the Patisserie Bakery \& Café Sanur. Product innovation has a positive and significant effect on consumers' repurchase intention at Patisserie Bakery \& Café Sanur. Consumer satisfaction has a positive and significant effect on consumers' repurchase intention at Patisserie Bakery \& Café Sanur. Consumer satisfaction mediates the positive influence of product innovation on consumers' repurchase intention at Patisserie Bakery \& Café Sanur. Suggestions that can be recommended as producers, Patisserie Bakery \& Café Sanur must maintain a good taste and increase production so that consumers are happy and continue to want to shop. Continue to maintain the satisfaction of consumers both in terms of service, display of food, and the taste of the food itself which is the main thing that is sought by every consumer.

Keywords: product innovation, customer satisfaction, repurchase intention
\end{abstract}




\section{PENDAHULUAN}

Bisnis restaurant saat ini sedang meningkat di pasaran. Para pemilik usaha harus dapat mempertahankan pangsa pasarnya. Restaurant harus menciptakan konsep yang berbeda untuk menarik minat konsumen untuk melakukan pembelian (Sari, 2016). Ranjbarian et al. (2012) menyatakan niat beli konsumen merupakan bagian dari komponen perilaku dalam sikap mengkonsumsi. Minat beli konsumen adalah tahap dimana konsumen membentuk pilihan mereka diantara beberapa merek yang tergabung dalam perangkat pilihan. Kemudian pada akhirnya melakukan suatu pembelian pada suatu altenatif yang paling disukainya atau proses yang dilalui konsumen untuk membeli suatu barang atau jasa yang didasari oleh bermacam pertimbangan (Rumahak dan Rahayu, 2016).

Kotler dan Keller (2009:53) menyatakan minat beli ulang adalah kenginan dan tindakan konsumen untuk membeli ulang suatu produk, karena adanya kepuasan yang diterima sesuai yang dinginkan dari suatu produk. Pembelian ulang menurut Pamenang dan Susanto (2016) adalah kegiatan pembelian yang dilakukan lebih dari satu kali atau beberapa kali. Kepuasan yang diperoleh seorang konsumen, dapat mendorong seseorang untuk melakukan pembelian ulang, menjadi loyal terhadap produk tersebut ataupun loyal terhadap toko tempat dia membeli barang tersebut sehingga konsumen dapat menceritakan hal-hal yang baik kepada orang lain (Prastyaningsih, 2014).

Konsumen yang melakukan pembelian ulang menjadi salah satu tujuan kegiatan pemasaran yang dilakukan perusahaan. Niat membeli ulang terjadi setelah konsumen melakukan pembelian dimana setelah konsumen membeli atau 
mengkonsumsi produk yang dihasilkan perusahaan maka konsumen berniat untuk membeli ulang produk atau jasa yang sama. Hal ini seperti yang dikemukakan bahwa Trisnawati et al. (2012) niat pembelian ulang (repurchase intention) adalah perilaku yang muncul sebagai respon terhadap objek.

Pada umumnya, niat beli ulang merupakan minat pembelian yang didasarkan atas pengalaman pembelian yang telah dilakukan dimasa lalu. Minat beli ulang yang tinggi mencerminkan tingkat kepuasan yang tinggi dari konsumen ketika memutuskan untuk mengadopsi suatu produk (Kotler dan Keller, 2009:81). Trisnawati et al. (2012) menyatakan niat konsumen untuk melakukan pembelian ulang dipengaruhi oleh banyak faktor, selain dari pengalaman dirinya sendiri tetapi juga dapat dipengaruhi oleh inovasi produk yang ditawarkan (Eriza, 2017).

Kunci utama untuk memenangkan persaingan adalah dengan menciptakan inovasi, inovasi harus diciptakan perusahaan karena inovasi adalah salah satu sumber pertumbuhan perusahaan. Inovasi produk adalah salah satu faktor yang paling diandalkan oleh seorang pemasar dalam memasarkan suatu produk. Inovasi akan meningkatkan nilai tambah suatu produk, inovasi akan menciptakan suatu produk baru yang dapat memberikan solusi yang lebih baik bagi pemecahan masalah yang dihadapi konsumen (Rumahak dan Rahayu, 2016). Inovasi yang tinggi baik itu inovasi proses maupun inovasi produk akan meningkatkan kemampuan perusahaan menciptakan produk yang berkualitas. Kualitas produk yang tinggi akan meningkatkan keunggulan bersaing perusahaan yang pada akhirnya berdampak pada niat pembelian konsumen (Pertiwi dan Sukawati, 2017). 
Beberapa penelitian menyatakan inovasi produk memiliki pengaruh positif terhadap niat beli ulang konsumen. Agus dan Gita (2009) menyatakan inovasi produk memiliki pengaruh positif terhadap niat beli ulang konsumen. Cynthiadewi dan Hatammimi (2014) menyatakan inovasi produk memiliki pengaruh positif terhadap niat beli ulang konsumen. Widjaja (2016) membuktikan bahwa secara positif inovasi produk memiliki pengaruh terhadap niat beli ulang konsumen.

Tingkat kepuasan pelanggan mencerminkan seberapa besar tingkat kualitas dan citra dari suatu produk. Husein (2002:51) menyatakan bahwa Kepuasan konsumen adalah tingkat perasaan konsumen setelah membandingkan kenyataan dengan harapannya. Kepuasan yang hendak dicapai dan diberikan kepada konsumen ini terbagi ke dalam dua bagian. Pertama, kepuasan yang diperoleh konsumen atas manfaat dan kualitas dari suatu produk. Sebagai contoh, kepuasan yang didapat seorang konsumen setelah menikmati makanan yang dipesannya di suatu restoran. Kedua yaitu kepuasan yang diperoleh konsumen tersebut atas makanan tadi yang sifatnya tidak berwujud, seperti pelayanan yang cepat dan ramah (Cynthiadewi dan Hatammimi, 2014).

Beberapa penelitian menyatakan kepuasan konsumen memiliki pengaruh positif terhadap niat pembelian ulang. Penelitian Pamenang dan Susanto (2016) menunjukkan jika kepuasan konsumen berpengaruh positif terhadap niat beli ulang produk. Cynthiadewi dan Hatammimi (2014) menyatakan kepuasan konsumen memiliki pengaruh positif terhadap niat beli ulang konsumen. Widjaja 
(2016) membuktikan bahwa secara positif kepuasan konsumen memiliki pengaruh terhadap niat beli ulang konsumen.

Kepuasan konsumen memiliki keterkaitan dengan inovasi produk seiring dengan meningkatnya niat beli ulang konsumen. Said (2016) menyatakan bahwa inovasi produk merupakan persepsi tentang sekumpulan asosiasi merek yang terbentuk dan lekat dibenak atau daya ingat konsumen. Konsumen menjadikan merek sebagai salah satu pertimbangan penting ketika hendak membeli suatu produk atau jasa. Secara rasional konsumen percaya bahwa merek tertentu bisa memberikan jaminan kualitas. Menurut Prahardjo et al. (2016) bahwa merek yang kuat dapat menentukan suatu rencana, visualisasi dan ekspektasi yang lebih baik terhadap kinerja dan kualitas dari suatu produk atau jasa yang akan diperoleh konsumen.

Beberapa penelitian menyatakan kepuasan konsumen memediasi pengaruh positif inovasi produk terhadap niat pembelian ulang. Hasil penelitian Agus dan Gita (2009) menemukan bahwa kepuasan konsumen mampu memediasi pengaruh inovasi produk terhadap niat pembelian ulang. Begitu juga dengan hasil penelitian Ebrahimi dan Tootoonkavan (2014) yang menemukan jika kepuasan konsumen mampu memediasi pengaruh inovasi produk terhadap niat pembelian ulang. Sari dan Yuniati (2016) menyatakan bahwa kepuasan konsumen secara positif memediasi pengaruh inovasi produk terhadap niat beli ulang konsumen.

Fenomena niat beli ulang konsumen yang terjadi saat ini, terbukti dengan sikap seseorang yang akan lebih percaya dengan inovasi produk yang dimiliki dan ditawarkan perusahaan sehingga dapat memberi pengaruh yang kuat terhadap 
keputusan untuk membeli atau menggunakan suatu produk atau jasa (Gunawan et al., 2016). Sebuah inovasi produk akan sangat berpengaruh terhadap konsumen yang tertarik dengan apa yang ditawarkan oleh perusahaan sehingga memiliki niat beli ataupun niat beli ulang (Ebrahimi dan Tootooonkavan, 2014).

Meningkatkan niat beli ulang konsumen tentu saja tidak tugas mudah bagi Bakery Patisserie \& Café Sanur. Bakery Patisserie \& Café Sanur sebagai salah satu usaha bidang kuliner yang berlokasi di daerah Sanur. Hidangan yang disajikan pada restaurant ini adalah european gluten-free. Bakery Patisserie \& Café Sanur dilengkapi dengan ricefields view yang memberikan atmosphere rustic sebagai daya tarik kepada konsumen, pemilihan ricefields view dikarenakan suasana jalan di daerah Sanur yang masih tenang dan ramai, sehingga membuat suasana nyaman dan tenang bagi konsumen untuk berkumpul serta menikmati hidangan makanan. Berbagai pilihan menu eropa yang bebas gluten dikombinasi dengan menu vegetarian merupakan inovasi yang disajikan di restaurant ini, menu pilihan yang ada seperti Yellowfin tuna carpaccio, Blackened albacore tuna, Mediterranean green salad with calamari, Jamon serrano, Vietnamese grilled chicken dan Tasmanian salmon tartare. Sardine restaurant juga memiliki beberapa main course menu yaitu Grilled sardine, Grilled hamachi, Sautéed wild snapper, Sauteed Kingfish serta Pan roasted mahi-mahi.

Melalui pemaparan masalah yang telah dijabarkan, didukung dengan karya ilmiah dan teori tujuan dari karya ilmiah ini yang hendak dicapai 1) Bagaimana pengaruh inovasi produk terhadap kepuasan konsumen di Bakery Patisserie \& Café Sanur, 2) Bagaimana pengaruh inovasi produk terhadap niat pembelian ulang 
konsumen di Bakery Patisserie \& Café Sanur, 3) Bagaimana pengaruh kepuasan konsumen terhadap niat pembelian ulang konsumen di Bakery Patisserie \& Café Sanur, dan 4) Bagaimana peran kepuasan konsumen memediasi pengaruh inovasi produk terhadap kepuasan konsumen di Bakery Patisserie \& Café Sanur.

Theory of Trying adalah teori yang dikembangkan oleh Bagozzi dan Warshaw dalam usaha menjelaskan ketidakpastian konsumen ketika pencapaian dari tujuan konsumsi tidak sepenuhnya berada dalam kontrol kemauan seseorang. Menurut Agarwal dan Sinha (2003:112) disebutkan bahwa Theory of Trying dimaksudkan untuk menjelaskan hubungan antara niat dan perilaku dengan menyelidiki orang-orang yang berupaya keras untuk melaksanakan perilaku tersebut. Hal ini berarti apabila seorang individu mencoba untuk mencapai suatu tujuan, maka individu tersebut akan melihatnya sebagai beban potensial yang hanya memiliki dua kemungkinan yaitu kemungkinan mencoba tetapi tidak berhasil dan yang kedua adalah gagal untuk mencoba.

Suprapti (2010:68) persepsi merupakan sebuah proses yang harus dilalui oleh konsumen untuk memilih, mengorganisasi, menginterpretasi stimuli ke dalam sebuah gambaran yang bersifat koheren. Menurut Mangkunegara (2011:21) Perilaku konsumen didefinisikan sebagai tindakan individu yang secara langsung terlibat dalam usaha memperoleh dan menggunakan barang-barang serta jasa ekonomis termasuk proses pengambilan keputusan yang mendahului dan menentukan tindakan-tindakan tersebut. Perilaku konsumen (consumer behavior) adalah proses yang terjadi pada konsumen ketika memutuskan untuk membeli, apa yang dibeli, dimana, kapan, dan bagaimana membelinya. Sehingga, dapat 
disimpulkan bahwasanya perilaku konsumen merupakan suatu proses yang terusmenerus (berkesinambungan).

Pavlou (2003) mendefinisikan perilaku niat beli sebagai niat konsumen untuk terlibat dalam berbagai hubungan pertukaran online dengan penjual pada suatu web, seperti berbagi informasi bisnis, menjaga hubungan bisnis, dan melakukan transaksi bisnis. Didalam konsep B2C e-commerce, konsumen memerlukan niat untuk menentukan penjual online mana yang dipilih, website untuk mendapatkan dan memberikan informasi dan kemudian menyelesaikan transaksi dengan membeli produk atau jasa tersebut. Perilaku niat didefinisikan Mowen and Minor (2007) sebagai keinginan konsumen untuk berperilaku menurut cara tertentu dalam rangka memiliki, membuang, dan menggunakan produk atau jasa.

Tujuan pemasaran adalah memenuhi dan memuaskan kebutuhan dan keinginan konsumen sasaran. Niat membeli merupakan keputusan yang mempelajari mengapa konsumen membeli suatu produk, pemasar akan mencari apa sebab-sebab seorang pelanggan untuk membeli pada suatu merek atau produk tertentu. Meningkatnya niat membeli akan membawa dampak yang positif terhadap penjualan produk di pasar. Sementara itu minat beli ulang pada dasarnya adalah perilaku pelanggan dimana pelanggan merespon positif terhadap kualitas pelayanan dan berniat melakukan kunjungan kembali atau mengkonsumsi kembali produk perusahaan tersebut. Menurut Kotler (2009:255) dalam proses pembelian, niat beli atau niat pembelian ulang konsumen ini berkaitan erat dengan motif yang dimilikinya untuk memakai ataupun membeli produk tertentu. 
Inovasi adalah produk atau jasa yang dipersepsikan oleh konsumen sebagai produk atau jasa baru. Secara sederhana, inovasi dapat diartikan sebagai terobosan yang berkaitan dengan produk-produk baru. Namun Kotler dan Keller (2009:274) menambahkan bahwa inovasi tidak hanya terbatas pada pengembangan produk-produk atau jasa-jasa baru. Inovasi juga termasuk pada pemikiran bisnis baru dan proses baru. Inovasi juga dipandang sebagai mekanisme perusahaan untuk beradaptasi dalam lingkungan yang dinamis. Schiffman dan Kanuk (2008:437) inovasi mempunyai 4 (empat) ciri yaitu:

(1). Memiliki kekhasan / khusus artinya suatu inovasi memiliki ciri yang khas dalam arti ide, program, tatanan, sistem, termasuk kemungkinan hasil yang diharapkan. (2). Memiliki ciri atau unsur kebaruan, dalam arti suatu inovasi harus memiliki karakteristik sebagai sebuah karya dan buah pemikiran yang memiliki kadar orisinalitas dan kebaruan. (3). Program inovasi dilaksanakan melalui program yang terencana, dalam arti bahwa suatu inovasi dilakukan melalui suatu proses yang yang tidak tergesa-gesa, namun ke-inovasian dipersiapkan secara matang dengan program yang jelas dan direncanakan terlebih dahulu. (4). Inovasi yang digulirkan memiliki tujuan, program inovasi yang dilakukan harus memiliki arah yang ingin dicapai, termasuk arah dan strategi untuk mencapai tujuan tersebut.

Menurut Tjiptono (2006:236) menjelaskan adanya beberapa indikator dari inovasi produk, yaitu:

Perluasan lini (line extensions) yaitu produk yang dihasilkan perusahaan tidaklah benar-benar baru tetapi relatif baru untuk sebuah pasar. 
Produk baru (me too - product) yaitu produk baru bagi perusahaan tetapi tidak baru bagi pasar.

Produk benar - benar baru (new - to - the - world - product) adalah produk yang termasuk baru baik bagi perusahaan maupun pasar.

Kotler dan Armstrong (2012:70) kepuasan pelanggan adalah suatu tingkatan dimana perkiraan kinerja produk sesuai dengan harapan pembeli. Sedangkan kepuasan pelanggan menurut Zeithaml, Parasuraman dan Malhotra (2002:104) adalah, "Customer's evaluation of a product or service in terms of whether that product or service has met the customer's needs and expectations". Dimana menurutnya kepuasan pelanggan adalah penilaian pelanggan atas produk ataupun jasa dalam hal menilai apakah produk atau jasa tersebut telah memenuhi kebutuhan dan ekspektasi pelanggan.

Menurut Kotler and Armstrong (2012: 37-40) faktor-faktor penentu kepuasan pelanggan terbagi atas lima bagian. Konsumen akan merasa puas setelah membeli atau menggunakan produk yang telah dibelinya ternyata kualitas produk sangat baik. Contoh, konsumen akan merasa puas terhadap makanan yang dibeli apabila rasa makanan tersebut memiliki rasa yang enak, dan tidak ada rasa yang tidak mengenakkan (Jimmi, 2015). Untuk konsumen yang sensitif, biasanya harga yang murah adalah sumber kepuasan yang penting karena mereka akan mendapatkan nilai uang yang tinggi, komponen harga ini relatif tidak penting bagi mereka yang tidak sensitif terhadap harga.

Untuk memuaskan pelanggan, suatu perusahaan hendaknya terlebih dahulu harus dapat memuaskan karyawan agar produk yang dihasilkan tidak rusak 
kualitasnya dan pelayanan kepada pelanggan dapat diberikan lebih baik lagi, jika karyawan merasa puas akan lebih mudah bagi mereka untuk menerapkan kepada pelanggan bagaimana rasa puas itu.

Faktor ini relatif penting karena kepuasan pelanggan timbul pada saat ia sedang mengkonsumsi produk tertentu, hal ini disebabkan karena merek produk tersebut sudah tercipta dengan baik, baik dari segi kualitas, harga yang tidak murah karena harga yang mahal identik dengan kualitas produk yang tinggi dan sebaiknya serta pelayanan yang diberikan (Ria dan Gatot, 2014).

Konsumen akan semakin puas apabila tempat mudah dicapai dan juga nyaman Dengan mengetahui kelima faktor ini, tentu tidak cukup bagi perusahaan untuk merancang strategi dan program peningkatan kepuasan konsumen. Kontribusi faktor ini juga dapat berubah dari waktu ke waktu untuk suatu industri. Besarnya bobot relatif mudah diketahui dengan melakukan survey. Dalam survey, konsumen dapat dinyatakan secara langsung mengenai kepuasan mereka dan tingkat kepuasan mereka setelah menggunakan produk dan jasa.

Beberapa penelitian menyebutkan inovasi produk memiliki pengaruh terhadap kepuasan konsumen. Penelitian Ihda et al. (2014) menyatakan inovasi produk memiliki pengaruh positif terhadap kepuasan konsumen. Hasil penelitian Nanda (2016) menunjukkan jika inovasi produk berpengaruh positif terhadap kepuasan konsumen secara signifikan. Begitu juga dengan hasil penelitian Tahir et al. (2016) yang menemukan jika inovasi produk berpengaruh positif signifikan terhadap kepuasan konsumen. Berdasarkan hasil penelitian tersebut, diajukan hipotesis pertama sebagai berikut. 
$\mathrm{H}_{1}$ : Inovasi produk berpengaruh positif dan signifikan terhadap kepuasan konsumen.

Kotler dan Keller (2009:117) menjelaskan inovasi produk akan menjadi salah satu faktor yang dapat mempengaruhi niat konsumen untuk melakukan pembelian ulang. Beberapa penelitian menyatakan citra merek memiliki pengaruh positif terhadap niat pembelian ulang. Hasil penelitian Tahir et al. (2016) menemukan bahwa inovasi produk merupakan faktor penting yang memiliki pengaruh positif terhadap niat beli ulang konsumen. Begitu juga dengan hasil penelitian Nanda (2016) yang menemukan jika inovasi produk berpengaruh positif signifikan terhadap repurchase intention. Ihda et al. (2014) menyatakan bahwa inovasi produk secara positif memiliki pengaruh terhadap niat beli ulang konsumen. Berdasarkan pemahaman tersebut dapat dirumuskan hipotesis kedua sebagai berikut.

$\mathrm{H}_{2}$ : Inovasi produk berpengaruh positif dan signifikan terhadap niat pembelian ulang konsumen.

Shiffman dan Kanuk (2008) mengindikasikan kepuasan konsumen akan mengindikasikan atau secara langsung akan meningkatkan niat beli ulang konsumen. Beberapa penelitian menyatakan kepuasan konsumen memiliki pengaruh positif terhadap niat pembelian ulang. Penelitian Nanda (2016) menunjukkan jika kepuasan konsumen berpengaruh positif terhadap niat beli ulang produk. Tika (2013) menyatakan kepuasan konsumen memiliki pengaruh positif terhadap niat beli ulang konsumen. Tahir et al. (2016) membuktikan bahwa secara positif kepuasan konsumen memiliki pengaruh terhadap niat beli ulang 
konsumen. Berdasarkan pemahaman tersebut dapat dirumuskan hipotesis ketiga sebagai berikut.

$\mathrm{H}_{3}$ : kepuasan konsumen mempengaruhi niat pembelian ulang konsumen secara positif

Niat beli ulang konsumen sangat dipengaruhi secara positif dan signifikan oleh inovasi produk dan kepuasan konsumen (Shiffman dan Kanuk, 2008). Kotler dan Keller (2009:72) penilaian yang obyektif terhadap niat beli ulang dapat dibantu dengan inovasi produk dan penilaian terhadap kepuasan konsumen.

Penelitian Tika (2013) menunjukkan jika kepuasan konsumen mampu memediasi pengaruh positif inovasi produk terhadap niat beli ulang produk. Nanda (2016) menyatakan kepuasan konsumen memediasi pengaruh inovasi produk terhadap niat beli ulang produk. Tahir et al. (2016) membuktikan bahwa secara positif kepuasan konsumen memiliki pengaruh mediasi dalam hubungan inovasi produk terhadap niat beli ulang konsumen. Berdasarkan hasil penelitian tersebut, diajukan hipotesis ke empat sebagai berikut.

$\mathrm{H}_{4}$ : kepuasan konsumen memediasi pengaruh inovasi produk terhadap niat pembelian ulang konsumen secara signifikan.

Skema model konseptual ini menjelaskan bahwa kepuasan konsumen memediasi pengaruh positif inovasi produk terhadap niat beli konsumen dapat dilihat pada Gambar 1 berikut:

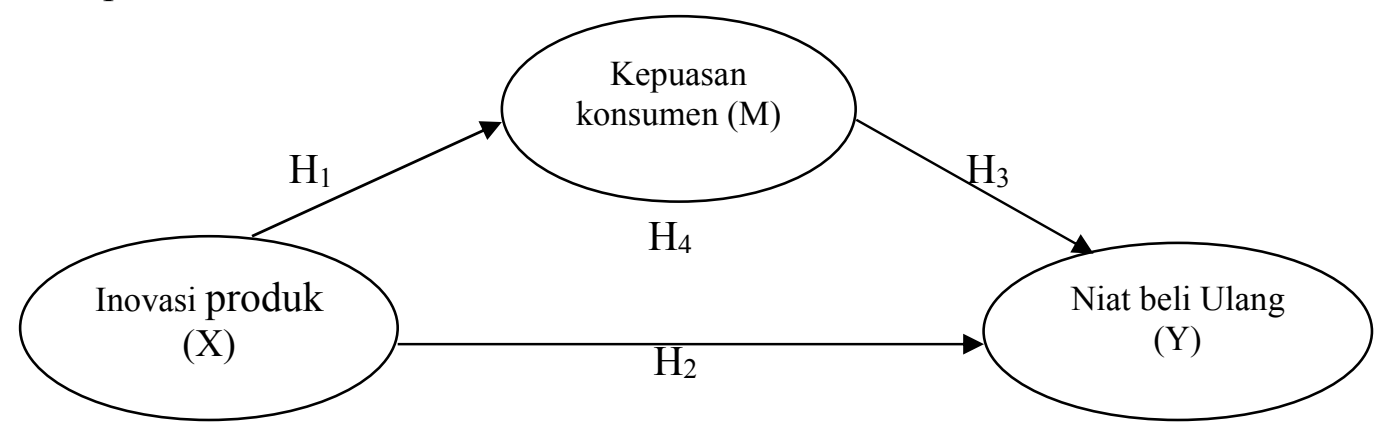

Gambar 1 Kerangka Konseptual 


\section{METODE PENELITIAN}

Karya ilmiah ini menggunakan metode mendeskripsikan atau memberi gambaran terhadap obyek yang diteliti melalui data sampel atau populasi sebagaimana adanya (Sugiyono, 2014:29). Pendekatan yang digunakan dalam penelitian ini adalah pendekatan kuantitatif. Secara umum penelitian ini bertujuan untuk mengetahui kepuasan konsumen memediasi pengaruh inovasi produk terhadap niat pembelian ulang konsumen secara signifikan. Penelitian ini dilakukan di Bakery Patisserie \& Café Sanur yang berlokasi di Jalan Danau Buyan 5B Sanur dengan menyasar orang-orang yang mengetahui Bakery Patisserie \& Café Sanur dan sudah pernah menikmati berbagai jenis sajian di Bakery Patisserie \& Café Sanur, dengan alasan untuk memenangkan persaingan di bidang kuliner Bakery Patisserie \& Café Sanur harus mampu memberikan kesan yang menarik dengan mengembangkan inovasi produk dengan menyajikan makanan yang sehat dan enak kepada konsumen sehingga memiliki rasa puas pada Bakery Patisserie \& Café Sanur.

Obyek dalam penelitian adalah karyawan Bakery Patisserie \& Café Sanur. Variabel kepuasan konsumen memediasi pengaruh inovasi produk terhadap niat pembelian ulang konsumen secara signifikan.

Jenis data kuantitatif dan kualitatif yang dipergunakan seperti data jumlah konsumen, jawaban responden terhadap kuesioner dan seperti sejarah perusahaan, struktur organisasi dan aktivitas perusahaan.Sumber data primer dan sekunder yang dipergunakan seperti observasi dan pemberian kuesioner kepada responden 
dan sejarah berdirinya perusahaan, struktur organisasi perusahaan, dan jumlah karyawan.

Populasi dalam penelitian ini digunakan 11 indikator yang terdiri dari tiga pertanyaan dari variabel niat pembelian ulang, tiga pertanyaan dari inovasi produk dan lima pertanyaan dari kepuasan konsumen sehingga jumlah responden yang digunakan pada Bakery Patisserie \& Café Sanur, yang belum diketahui jumlahnya (Sugiyono, 2013:68).

Uji validitas menyatakan sebuah instrumen dikatakan valid jika item yang mempunyai korelasi positif dengan kriterum (skor total) serta korelasi tinggi menunjukkan bahwa item tersebut mempunyai validitas yang tinggi pula. Syarat minimum untuk dianggap memenuhi syarat adalah kalau $r=0,3$ ”.Uji reabilitas ditunjukkan dengan angka indeks yang konsistensi suatu alat ukur dalam mengukur gejala yang sama. Uji reabilitas mampu menunjukan sejauh mana instrument dapat dipercaya dan diharapkan. Nilai suatu instrumen dikatakan reliabel bila nilai Alpha Cronbach $\geq 0,6$.

Teknik analisis data yang digunakan dalam penelitian ini adalah teknik analisis jalur (path analysis). Analisis jalur merupakan perluasan dari analisis regresi linier berganda, untuk menaksir hubungan kausalitas antar variabel yang berjenjangberdasarkan teori (Utama, 2009:135).

Pengaruh langsung inovasi produk (X) terhadap kepuasan konsumen (M) ditunjukkan oleh koefisien jalur a, pengaruh langsung inovasi produk $(\mathrm{X})$ terhadap niat pembelian ulang $(\mathrm{Y})$ ditunjukkan oleh koefisien jalur $\mathrm{c}$, dan pengaruh kepuasan konsumen $(\mathrm{M})$ terhadap niat pembelian ulang $(\mathrm{Y})$ ditunjukkan oleh koefisien jalur $b$. 
Pengaruh tidak langsung inovasi produk $(\mathrm{X})$ terhadap niat pembelian ulang (Y) diperoleh dengan mengalikan a dengan $\mathrm{b}$.

Pengujian hipotesis mediasi dapat dilakukan dengan prosedur yang dikembangkan oleh Sobel (1982) dan dikenal dengan Uji Sobel (Sobel Test). Uji Sobel digunakan dengan menguji kekuatan pengaruh tidak langsung variabel pengetahuan inovasi produk $(\mathrm{X})$ terhadap variabel niat pembelian ulang $(\mathrm{Y})$ melalui variabel kepuasan konsumen (M) dihitung dengan cara mengalikan koefisien jalur X terhadap M (a) dengan koefisien jalur M terhadap Y (b) atau ab. Standar error koefisien a dan $b$ ditulis dengan $S_{a}$ dan $S_{b}$, besarnya standar error tidak langsung (indirect effect) $\mathrm{S}_{\mathrm{ab}}$.

\section{HASIL DAN PEMBAHASAN}

Tabel 1.

Rangkuman Hasil Uji Validitas

\begin{tabular}{cllcc}
\hline No & Variabel & Indikator & Korelasi & Keterangan \\
\hline 1 & Inovasi Produk (X) & $\mathrm{X} 1.1$ & 0,815 & Valid \\
& & $\mathrm{X} 1.2$ & 0,802 & Valid \\
& \multirow{2}{*}{2} & $\mathrm{X} 1.3$ & 0,894 & Valid \\
& Kepuasan Konsumen (M) & $\mathrm{M} .1$ & 0,710 & Valid \\
& & $\mathrm{M} .2$ & 0,660 & Valid \\
& & $\mathrm{M} .3$ & 0,838 & Valid \\
& \multirow{2}{*}{3} & $\mathrm{M} .4$ & 0,736 & Valid \\
& \multirow{2}{*}{ Niat Beli Ulang (Y) } & $\mathrm{M} .5$ & 0,701 & Valid \\
& & $\mathrm{Y} .1$ & 0,770 & Valid \\
& & $\mathrm{Y} .2$ & 0,754 & Valid \\
& & $\mathrm{Y} .3$ & 0,857 & Valid \\
\hline
\end{tabular}

Sumber: data diolah, 2018

Tabel 1. diketahui bahwa masih-masing indikator variabel memiliki nilai person correlation lebih besar dari 0,30 , maka ini berarti indikator/pertanyaan yang digunakan layak digunakan untuk mengukur apa yang seharusnya diukur, dan dapat mengungkap data dari variabel yang diteliti secara tepat.

Uji Reliabilitas 
Tabel 2.

Hasil Uji Reliabilitas

\begin{tabular}{clcc}
\hline \multirow{2}{*}{ No } & \multirow{2}{*}{ Variabel } & $\begin{array}{c}\text { Cronbach's } \\
\text { Alpha }\end{array}$ & \multirow{2}{*}{ Keterangan } \\
\hline 1 & Inovasi produk $(\mathrm{X})$ & 0,782 & Reliabel \\
2 & Kepuasan konsumen $(\mathrm{M})$ & 0,780 & Reliabel \\
3 & Niat beli ulang (Y) & 0,708 & Reliabel \\
\hline Sumber: data diolah, 2018 & &
\end{tabular}

Tabel 2. diketahui bahwa nilai Cronbach's Alpha untuk masing-masing variabel $>0,6$, ini berarti alat ukur tersebut akan memberikan hasil yang konsisten apabila alat ukur tesebut digunakan kembali untuk meneliti obyek yang sama.

Tabel 3.

Rekapitulasi Hasil Regresi Struktur 1

\begin{tabular}{llccc}
\hline & Model & $\begin{array}{c}\text { Standardized } \\
\text { Coefficients } \\
\text { Beta }\end{array}$ & T & Sig. \\
\hline (Constant) & & 0.624 & 2.165 & 0.033 \\
Inovasi produk & 0.838 & 11.734 & 0.000 \\
$\mathrm{R}^{2}$ & & & \\
F Statistik & $: 137,697$ & & & \\
Sig.F & $: 0,000$ & & & \\
\hline Sumber: data diolah, & & &
\end{tabular}

Berdasarkan laporan pada Tabel 3, maka persamaan strukturalnya adalah sebagai berikut:

$$
\begin{aligned}
& \mathrm{M}=0.838 \mathrm{X} \\
& \mathrm{Se}=0.000 \\
& \mathrm{t}=11.734
\end{aligned}
$$

Sig. $\mathrm{t}=0.000$

F Statistik $=137.697$

Sig. $F=0.000$

$\mathrm{R}^{2}=0.560$.

Berdasarkan laporan pada Tabel 4, maka persamaan strukturalnya adalah sebagai berikut:

$$
\begin{aligned}
\mathrm{Y} & =0.442 \mathrm{X}+0.489 \mathrm{M} \\
\mathrm{Se} & =0.000
\end{aligned}
$$


$\mathrm{t}=4.108$ (inovasi produk) dan 5.087 (kepuasan konsumen)

Sig. $\mathrm{t}=0.000$

F Statistik $=84.216$

Sig. $F=0.000$

$\mathrm{R}^{2}=0.612$

Tabel 4.

Rekapitulasi Hasil Regresi Struktur 2 Standardized Coefficients

\begin{tabular}{|c|c|c|c|}
\hline Model & Beta & $\mathbf{T}$ & Sig. \\
\hline$\overline{\text { (Constant) }}$ & 0.137 & 0.466 & 0.642 \\
\hline Inovasi produk & 0.442 & 4.108 & 0.000 \\
\hline Kepuasan konsumen & 0.489 & 5.087 & 0.000 \\
\hline $\mathrm{R}^{2} \quad: 0,612$ & & & \\
\hline F Statistik & & & \\
\hline$: 0,000$ & & & \\
\hline
\end{tabular}

Sumber: data diolah,

Hasil perhitungan menunjukan perbandingan nilai z hitung sebesar 6,873 > z tabel sebesar 0,96, maka Ho ditolak dan Hi diterima. Artinya kepuasan konsumen memediasi pengaruh inovasi produk terhadap niat beli ulang konsumen pada Bakery Patisserie \& Café Sanur

\section{HASIL DAN PEMBAHASAN}

Hasil analisis data inovasi produk memberikan pengaruh positif terhadap kepuasan konsumen, terlihat adanya inovasi produk yang dimiliki oleh Bakery Patisserie \& Café Sanur akan memberikan pengaruh positif terhadap kepuasan konsumen pada Bakery Patisserie \& Café Sanur. Oleh karena itu, sikap dan tindakan konsumen terhadap suatu produk sangat ditentukan oleh inovasi-inovasi yang dimiliki oleh Bakery Patisserie \& Café Sanur tersebut untuk meningkatkan kepuasan konsumen terhadap produk. 
Hasil penelitian ini searah dengan penelitian Ihda et al. (2014) menyatakan inovasi produk memiliki pengaruh positif terhadap kepuasan konsumen. Hasil penelitian Nanda (2016) menunjukkan jika inovasi produk berpengaruh positif terhadap kepuasan konsumen secara signifikan. Begitu juga dengan hasil penelitian Tahir et al. (2016) yang menemukan jika inovasi produk berpengaruh positif signifikan terhadap kepuasan konsumen.

Hasil analisis data diketahui bahwa inovasi produk memberikan pengaruh positif terhadap niat beli konsumen. Hal ini mengandung arti bahwa semakin baik inovasi produk yang dimiliki oleh Bakery Patisserie \& Café Sanur berakibat positif pada niat beli ulang konsumen untuk membeli. Inovasi produk adalah satu elemen bauran pemasaran yang menghasilkan ide-ide baru dan kreatif terhadap suatu produk yang dipasarkan, dengan adanya inovasi produk yang sesuai dengan keinginan konsumen akan memberikan respon positif terhadap niat beli ulang konsumen di Bakery Patisserie \& Café Sanur.

Hasil penelitian ini didukung oleh penelitian Tahir et al. (2016) menemukan bahwa inovasi produk merupakan faktor penting yang memiliki pengaruh positif terhadap niat beli ulang konsumen. Begitu juga dengan hasil penelitian Nanda (2016) yang menemukan jika inovasi produk berpengaruh positif signifikan terhadap repurchase intention. Ihda et al. (2014) menyatakan bahwa inovasi produk secara positif memiliki pengaruh terhadap niat beli ulang konsumen.

Hasil analisis data diketahui bahwa kepuasan konsumen memberikan pengaruh positif terhadap niat beli konsumen. Hal ini mengandung arti bahwa 
semakin baik kepuasan konsumen yang dirasakan akan secara langsung meningkatkan niat beli ulang konsumen di Bakery Patisserie \& Café Sanur. Konsumen akan mempersepsikan kepuasannya dengan rasa senang, bahagia dan ingin berkunjung kembali ke Bakery Patisserie \& Café Sanur untuk menikmati produk yang ditawarkan oleh Bakery Patisserie \& Café Sanur, yang pada gilirannya berkontribusi terhadap intensitas pembelian ulang konsumen.

Hasil penelitian ini didukung oleh penelitian Nanda (2016) menunjukkan jika kepuasan konsumen berpengaruh positif terhadap niat beli ulang produk. Tika (2013) menyatakan kepuasan konsumen memiliki pengaruh positif terhadap niat beli ulang konsumen. Tahir et al. (2016) membuktikan bahwa secara positif kepuasan konsumen memiliki pengaruh terhadap niat beli ulang konsumen.

Hasil analisis data diketahui bahwa kepuasan konsumen memediasi pengaruh inovasi produk terhadap niat beli ulang konsumen secara positif. Hal ini mengandung arti bahwa semakin baik rasa puas konsumen akan memberikan peran positif terhadap inovasi produk yang dimiliki oleh Bakery Patisserie \& Café Sanur yang akan berkontribusi untuk meningkatkan niat beli ulang konsumen. Konsumen akan memberikan penilaian yang obyektif terhadap inovasi produk untuk menciptakan kepuasan yang positif, baik itu tinggi atau rendah, akan memiliki pengaruh yang kuat terhadap intensitas pembelian ulang konsumen pada Bakery Patisserie \& Café Sanur.

Hasil penelitian ini sesuai dengan penelitian Tika (2013) menunjukkan jika kepuasan konsumen mampu memediasi pengaruh positif inovasi produk terhadap niat beli ulang produk. Nanda (2016) menyatakan kepuasan konsumen memediasi 
pengaruh inovasi produk terhadap niat beli ulang produk. Tahir et al. (2016) membuktikan bahwa secara positif kepuasan konsumen memiliki pengaruh mediasi dalam hubungan inovasi produk terhadap niat beli ulang konsumen.

\section{SIMPULAN DAN SARAN}

Berdasarkan pada pembahasan pada bab-bab sebelumnya, maka adapun halhal yang dapat disimpulkan yaitu inovasi produk berpengaruh positif dan signifikan terhadap kepuasan konsumen pada Bakery Patisserie \& Café Sanur. Inovasi produk berpengaruh positif dan signifikan terhadap kepuasan konsumen pada Bakery Patisserie \& Café Sanur. Kepuasan konsumen berpengaruh positif dan signifikan terhadap niat beli ulang konsumen pada Bakery Patisserie \& Café Sanur. Kepuasan konsumen memediasi pengaruh positif inovasi produk terhadap niat beli ulang konsumen pada Bakery Patisserie \& Café Sanur.

Berdasarkan simpulan, saran-saran yang dapat dilakukan sebagai produsen Bakery Patisserie \& Café Sanur untuk menghadapi permasalahan inovasi produk, harus tetap mempertahankan kualitas dan kuantitas dari produknya dengan menjaga rasa yang enak dan meningkatkan hasil produksi sehingga konsumen senang dan terus ingin berbelanja di karenakan dengan inovasi produk-produk yang baru dengan rasa yang berbeda dan enak meningkatkan niat beli ulang konsumen ke Bakery Patisserie \& Café Sanur.

Sebagai produsen Bakery Patisserie \& Café Sanur untuk menghadapi permasalahan kepuasan konsumen, harus tetap mempertahankan rasa puas dari konsumen baik dari segi layanan, tampilan makanan, serta rasa dari makanan itu sendiri yang menjadi hal utama yang dicari oleh setiap konsumen sehingga 
konsumen tidak merasa bosan terus berkunjung ke Bakery Patisserie \& Café Sanur untuk menikmati makanan yang ditawarkan dengan cita rasa dan layanan yang berbeda yang akan meningkatkan rasa puas konsumen untuk melakukan pembelian berulang-ulang di Bakery Patisserie \& Café Sanur.

Sebagai produsen Bakery Patisserie \& Café Sanur untuk mempertahankan niat beli ulang konsumen harus memiliki strategi tertentu untuk memenangkan persaingan, seperti adanya potongan harga bagi konsumen yang sudah pernah berkunjung lebih dari 2 kali dengan memberkan member, layanan special bagi yang sedang merayakan hari jadinya dan masih banyak lagi strategi yang harus dikembangkan oleh Bakery Patisserie \& Café Sanur untuk meningkatkan niat beli ulang konsumen. Strategi ini akan mampu memenangkan persaingan dalam merebut hati konsumen dikarenakan konsumen merasa mudah, aman dan cepat tentunya dengan perasaan yang puas apabila berbelanja di Bakery Patisserie \& Café Sanur.

\section{REFERENSI}

Agus, Rahayu., dan Gita, Anggraini. (2009). Pengaruh Inovasi Produk Terhadap Keputusan Pembelian Konsumen. Jurnal Strategic. 8(16): h: 1-20

Cynthiadewi, P. R., dan Hatammimi, J. (2014). The Influence of Electronic Word of Mouth Toward Brand Image and Purchase Intention of $13^{\text {th }}$ Shoes. International Journal Conference on Economics. 3(2): h: 10-11.

Ebrahimi, M. R., dan Tootooonkavan S. (2014). Investigating the Effect of Perceived Service Quality, Perceived Value, Brand Image, Trust, Customer Satisfaction on Repurchase Intention and Recommendation to Other Case Study: LG Company. European Journal of Business and Maagement. 6(34): h: 1-15 
Eriza, Z. N. (2017). Peran Medisi Citra Merek dan Persepsi Risiko pada Hubungan antara Electronic Word of Mouth (e-WOM) dan Minat Beli (Studi pada Konsumen Kosmetik E-Commerce di Solo Raya). Jurnal Komuniti. 9(1): h: 14-24

Gunawan, A., Diana, B., Murchandie, B.G., and Sitinjak, M.F. (2016). The Effect on Involvement and Electronic Word of Mouth (eWOM) on Brand Image and Its Impact on Consumers Brnd Switching of Mamypoko. International Journal of Economic and Maagement. 10(81): h: 19-31

Husein, Umar. 2002. Riset Pemasaran dan Perilaku Konsumen. Cetakan Kedua. Gramedia. Pustaka Utama. Jakarta

Kotler, Philip. (2009). Manajemen Pemasaran. Penerjemah. Jakarta: PT. Indeks

Kotler, Philip., and Armstrong, G. (2012). Principles of Marketing. 14th ed. New Jersey: Prentice Hall

Kotler, Philip., dan Keller, K. (2009). Manajemen Pemasaran. Jilid 1. Edisi ke 13. Diterjemahkan oleh Bob Sabran, Jakarta: Erlangga

Pamenang, W., dan Susanto, H. (2016). Analisis Pengaruh Kualitas Produk, Kepuasan Pelanggan dan Word of Mouth terhadap Minat Beli Ulang Konsumen (Studi Kasus pada Produk Kerupuk Ikan Lele UKM Minasari Cikaria Pati, Jawa Tengah). Jurnal Sains Pemasaran Indonesia. 15(3): h: 206-211

Pavlou, P. A. (2003). Consumer Acceptance of Electronic Commerce: Integrating Trust and Risk with the Thecnology acceptance Model. International Journal of Electronic Commerce. 7(3): h: 69-103

Pertiwi, K. Y., dan Sukawati, T. G. R. (2017). Brand Image Memediasi WOM terhadap Niat Menggunakan Wedding Service di Cahya Dewi Beauty Salon Denpasar. Jurnal Manajemen Unud. 6(5): h: 2609-2641

Prahardjo, A. Wilopo., dan Kurniawan. (2016). The Impact of Electronic Word of Mouth on Repurchase Intention Mediated by Brand Loyalty and Perceived. South East Asia Journal of Contempory Business. 11(2): h: 2289-1560

Prastyaningsih, Ayu Sari. (2014). Pengaruh Customer Experience Terhadap Repurchase Intention (Niat Membeli Ulang) (Survei Pada Konsumen Kfc Di Lingkungan Warga Rw 3 Desa Kandangrejo, Kedungpring, Lamongan). Jurnal Administrasi Bisnis. 16(1): h: 8-20 
Ranjbarian, B., Sanayei, A., Kaboli, M. R., and Hadadian, A. (2012). An Analysis of Brand Image, Perceived Quality, Customer Satisfaction and RePurchase Intention in Iranian Departemen Stores. International Journal of Economic and Maagement. 7(6): h: 40-48

Rumahak, M. D., dan Rahayu, B. (2016). Pengaruh Word of Mouth terhadap Purchase Intention Melalui Brand Image pada Lembaga Kursus Bahasa Inggris Dynamic English Course Pare. Jurnal Ekonomi dan Bisnis.1(2): h: $188-204$

Said, A. (2016). Pengaruh Brand Image, Word of Mouth dn Iklan terhadap Minat Menabung di BMT Se-Kabupaten Demak. Jurnal Ekonomi Syariah: 4(2): h: 318-333

Sari, F. P., dan Yuniati, T. (2016). Pengaruh Harga, Citra Merek dan Word of Mouth terhadap Keputusan Pembelian Konsumen. Jurnal Ilmu dan Riset Manajemen. 5(6): h: 16-20

Schiffman, Kanuk., \& Lazar. (2008). Consumer Behaviour $7^{\text {th }}$ Edition. (Perilaku Konsumen). Jakarta: PT.Indeks

Sugiyono. (2014). Metode Penelitian Kuantitatif, Kualitatif, dan R \& D. Bandung: CV Alfabeta

Suprapti, W. (2010). Prilaku Konsumen, Pemahaman Dasar dan Aplikasinya Dalam Strategi Pemasaran. Bali. Udayana University Press.

Suyana Utama, Made. (2009). Buku Ajar Aplikasi Analisis Kuantitatif. Denpasar :Fakultas Ekonomi Universitas Udayana

Tjiptono, F. (2006). Pemasaran Jasa. Jakarta: Gramedia Cawang

Trisnawati, Suroso., dan Kumorohadi. (2012). Analisis Faktor-faktor Kunci dari Niat Pembelian kembali secara Online (Studi Kasus pada Konsumen Fesh Shop). Jurnal Bisnis dan Ekonomi (JBE). 2(5): h:126-141

Widjaja, A. T. (2016). Pengaruh Word of Mouth dan Electronic Word of Mouth terhadap Purchase Intention: Sebuah Studi Kasus Mengenai Perilaku Konsumen terhadap Jasa Ojek Online Gojek. Jurnal Ekonomi dan Bisnis 53(12): h: 241-253 